\title{
THE IMPLEMENTATION OF SQ3R TECHNIQUE IN TEACHING READING COMPREHENSION
}

\author{
Susie Kusumayanthi ${ }^{1}$ Sely Mariam Maulidi ${ }^{2}$ \\ ${ }^{1,2}$ STKIP Pasundan, Indonesia \\ Email: susiekusuma7@gmail.com ${ }^{1}$ selymariam097@gmail.com ${ }^{2}$
}

First Received: August 2019

Final Proof Received: September 2019

\begin{abstract}
This study aims to describe the implementation of SQ3R in teaching reading comprehension and to identify students' responses to the implementation of SQ3R. This study uses a qualitative case study conducted at one of the state vocational school in Purwakarta. It involves 4 students. Data were collected through observation and interviews. The data from 2 instruments were analyzed qualitatively. The results of this study indicate that the implementation of SQ3R helps students to understand English words. According to Apandi (2011), SQ3R helps the students to understand English words. The students also responded positively to the implementation of SQ3R. Therefore, SQ3R is recommended to be implemented in teaching reading comprehension.
\end{abstract}

\section{Keywords: $S Q 3 R$, reading comprehension}

\section{INTRODUCTION}

Most Indonesian students have difficulties in reading English texts because English in Indonesia is a foreign language (Hamra \& Syatriana, 2010). In addition, many results of research also show that Indonesian students' ability in reading English texts is very low (Hamra \& Syatriana, 2010). In other words, a reading comprehension strategy is needed to improve reading comprehension. One of the strategies in teaching reading comprehension is SQ3R (survey, question, read, recite, and review). The SQ3R method is perhaps one of the oldest and most widely used methods (Lipson and Wixson (2003, as cited in Rahyana, Kasyulita, \& Rasyidah, 2016)). SQ3R, developed by Robinson (1941), consists of five steps: Survey, Question, Read, Recite, and Review (Baier, 2011). The first step is survey (S), by surveying headings and pictures, readers can activate their prior knowledge (Hedberg 2002). Surveying the text also helps the reader to get a greater understanding of the text. The second step is question (Q) This step gives a purpose for reading the text in more detail so that students should be ready for a more detail study of the text. Questioning also causes the reader to search for the answer to the question (Baier, 2011). It will arouse readers' curiosity about the text so that it can increase their comprehension about the text (Baier, 2011). The third step is read (R-1) that is reading to find the answers to the questions created in step 2. The fourth step is recite (R-2) that is restating the answers in step 3 by one's own words and then writing the response (Wright, 2003 as cited in Masruuroh, 2015). The last step is review (R-3) that is scanning the taken notes and observing the relationship between both, the main points and the supporting details (Robinson (1961 in Baier, 2011). In this step, students may write brief notes on their notebook for later review and study (Dishner, 1990).

According to Miller \& Veatch (2010), this method is important because it helps students to be "aware of a purpose of reading, overview of the text, read selectively, and 
review what is read". Some experiments have been done and they have proven that the SQ3R technique can improve the comprehension of students in reading English. Whorter (1992) states, that the SQ3R technique has been used successfully for many years, and it can improve the understanding and the retention of the student in reading.

As the stated above, an understanding approach that helps students think about the text they are reading and can activate their thinking then evaluate their knowledge through reading. The research includes: (a) what kind of experiences does the researcher have when teaching using SQ3R technique in teaching reading comprehension? And (b) what are the students` responses toward the implementation of the SQ3R technique in teaching reading comprehension?

The literature reviews this study focuses on reading skills. The research discusses the Implementation SQ3R (Survey, Question, Read, Recite, Review) technique in teaching reading comprehension. The research questions include: (a) what kind of experiences does the researcher have when teaching using SQ3R technique in teaching reading comprehension? And (b) what are the students' responses toward the implementation of the SQ3R technique in teaching reading comprehension?

\section{Process of SQ3R}

Based on the background above, according to Hamra \& Syatriana (2010), most Indonesian students have difficulties in reading English texts because English in Indonesia is a foreign language and many results of research also show that Indonesian students' ability in reading English texts is very low.

In other words, a reading comprehension strategy is needed to improve reading comprehension. One of the strategies in teaching reading comprehension is SQ3R method. From the explanation above it can be concluded that this study will raise the theme of reading skills entitled "The Implementation of SQ3R (Survey, Question, Read, Recite, and Review) Technique in Teaching Reading Comprehension".

The text used as the materials in this research was narrative text. For the first meeting, the researcher explained about what narrative text is. Such as, explaining definitions, generic structures, language future and social function in narrative text. After that, the researcher explained the steps SQ3R in reading. The students listened carefully to the researcher's explanation when the researcher explained about SQ3R. The researcher gave narrative texts to each student while explaining how to read using SQ3R. As stated by Lestari (2018), each step of SQ3R should be explained before implementing SQ3R because it will help the students in reading and understanding texts independently.

According to Marini (2014, as cited in Amin, Harmaini, \& Harha, 2008), SQ3R is five active steps of reading methods, surveying, questioning, reading, reciting, and reviewing. This method is used to absorb fully written information and helps students become good readers. The process of the implementation SQ3R shows as follow:

Table 1. The steps of the implementing SQ3R

\begin{tabular}{llll}
\hline \multirow{2}{*}{ SQ3R } & \multicolumn{1}{c}{ Activities } & \multicolumn{2}{c}{ Process } \\
\cline { 3 - 4 } SURVEY & $\begin{array}{l}\text { The researcher asked } \\
\text { the students to survey } \\
\text { the text by reading } \\
\text { about the title of the } \\
\text { text. }\end{array}$ & $\begin{array}{l}\text { "Look at the text, read the } \\
\text { title and write down the } \\
\text { title in the worksheet." }\end{array}$ & $\begin{array}{l}\text { Most students didn } \text { t listen } \\
\text { to the instruction from the } \\
\text { researcher. } \\
\end{array}$ \\
& & $\begin{array}{l}\text { The researcher explained } \\
\text { again and wrote down on } \\
\text { the whiteboard, in order for } \\
\text { the student to be more }\end{array}$ \\
\hline
\end{tabular}


understand. After the students understood about the survey (s) step, the students wrote down the title on the worksheet. For example The Title; Jack and the Beanstalk.

The researcher asked "Read each paragraph, for The students focused to the students to survey 5 minutes" read the paragraphs. each paragraph.

\begin{tabular}{|c|c|c|c|}
\hline & $\begin{array}{l}\text { The researcher asked } \\
\text { the students to survey } \\
\text { the difficult words of } \\
\text { the text. }\end{array}$ & $\begin{array}{l}\text { "Find the difficult word, } \\
\text { then look for the meaning } \\
\text { and write in the } \\
\text { worksheet, for } 5 \text { minutes" }\end{array}$ & $\begin{array}{l}\text { The students found the } \\
\text { difficult word and looked } \\
\text { for the meaning }\end{array}$ \\
\hline & $\begin{array}{l}\text { The researcher asked } \\
\text { the students to survey } \\
\text { the next pages. }\end{array}$ & $\begin{array}{l}\text { "How many pages left of } \\
\text { the text? Write them on } \\
\text { the worksheet." }\end{array}$ & $\begin{array}{l}\text { The students did the survey } \\
\text { for the next pages and wrote } \\
\text { down on worksheets. }\end{array}$ \\
\hline QUESTION (Q) & $\begin{array}{l}\text { The researcher asked } \\
\text { the students to write } \\
\text { questions based on } \\
\text { each paragraph of the } \\
\text { text. }\end{array}$ & $\begin{array}{l}\text { "Write questions about } \\
\text { the text and the } \\
\text { information of each } \\
\text { paragraph of the text, } \\
\text { which includes the } \\
\text { question when, where, } \\
\text { who and why; for } \\
\text { example: when this thing } \\
\text { came?" }\end{array}$ & $\begin{array}{l}\text { There were some students } \\
\text { who did not know the } \\
\text { meaning when writing } \\
\text { questions into English. } \\
\text { They actively asked the } \\
\text { researcher when they had } \\
\text { difficulty doing this step. } \\
\text { The researcher also guided } \\
\text { them when they had } \\
\text { difficulty doing the task. } \\
\text { Such as asking the students } \\
\text { to open a dictionary. }\end{array}$ \\
\hline $\begin{array}{l}\text { READ } \\
\text { (R 1) }\end{array}$ & $\begin{array}{l}\text { The researcher asked } \\
\text { the students to read } \\
\text { the text to find the } \\
\text { answers to the } \\
\text { questions developed } \\
\text { in step } 2 .\end{array}$ & $\begin{array}{l}\text { "Read the narrative text } \\
\text { for } 15 \text { minutes and find } \\
\text { the answer from the } \\
\text { question in step 2, then } \\
\text { write in worksheet." }\end{array}$ & $\begin{array}{l}\text { The students read the text } \\
\text { and focused to find the } \\
\text { answer from the question. }\end{array}$ \\
\hline \multirow[t]{3}{*}{$\begin{array}{l}\text { RECITE } \\
\text { (R 2) }\end{array}$} & $\begin{array}{l}\text { Then the researcher } \\
\text { asked the students to } \\
\text { write the main idea }\end{array}$ & $\begin{array}{l}\text { "Look for the main idea } \\
\text { and write it on the } \\
\text { worksheet." }\end{array}$ & $\begin{array}{l}\text { Students looked for the } \\
\text { main idea and write down } \\
\text { on a worksheet }\end{array}$ \\
\hline & $\begin{array}{l}\text { The researcher asked } \\
\text { students to write the } \\
\text { moral message of the } \\
\text { text }\end{array}$ & $\begin{array}{l}\text { "Then, write the moral } \\
\text { message of the text, write } \\
\text { down in the worksheet" }\end{array}$ & $\begin{array}{l}\text { The students focused to } \\
\text { write the moral message of } \\
\text { the text. }\end{array}$ \\
\hline & $\begin{array}{l}\text { Then the researcher } \\
\text { asked the students to } \\
\text { repeat (aloud) in their } \\
\text { own words what they } \\
\text { have read. Explain } \\
\text { what they have read } \\
\text { to someone else. }\end{array}$ & $\begin{array}{l}\text { "The next step, repeat } \\
\text { (aloud) in your own } \\
\text { words what you have } \\
\text { read. Explain what you } \\
\text { have read to someone } \\
\text { else." }\end{array}$ & $\begin{array}{l}\text { Some students found it } \\
\text { difficult to repeat using } \\
\text { their own words in English } \\
\text { language, and researchers } \\
\text { were asking students to } \\
\text { write what they have read in } \\
\text { Indonesian and then } \\
\text { translated it into English. }\end{array}$ \\
\hline \multirow[t]{2}{*}{$\begin{array}{l}\text { REVIEW } \\
\text { (R 3) }\end{array}$} & $\begin{array}{l}\text { The researcher asked } \\
\text { the students to review } \\
\text { the information in the } \\
\text { text. }\end{array}$ & $\begin{array}{l}\text { "Review information } \\
\text { about the text" }\end{array}$ & $\begin{array}{l}\text { The students focused } \\
\text { reviewing the information } \\
\text { about the text. }\end{array}$ \\
\hline & $\begin{array}{l}\text { The researcher asked } \\
\text { the students to recall } \\
\text { the points of the text } \\
\text { and the supporting } \\
\text { details. }\end{array}$ & $\begin{array}{l}\text { "Remember the key } \\
\text { points from supporting } \\
\text { texts." }\end{array}$ & $\begin{array}{l}\text { The student focused on } \\
\text { remembering the key points } \\
\text { from supporting texts. }\end{array}$ \\
\hline
\end{tabular}




\begin{tabular}{lll}
\hline $\begin{array}{l}\text { The researcher asked } \\
\text { the students to write a } \\
\text { summary of the text. }\end{array}$ & $\begin{array}{l}\text { "The last, make a } \\
\text { summary about the text } \\
\text { and write down in the } \\
\text { worksheet" }\end{array}$ & $\begin{array}{l}\text { The student focused to write } \\
\text { down the summary about } \\
\text { the text }\end{array}$ \\
\end{tabular}

The above table is taken from the experience of the researcher when teaching using SQ3R. Each step of SQ3R was done in two meetings. The activity includes the students surveyed the text by writing the title of the text and difficult words of the text on the survey worksheet. They also wrote some questions from the text on the worksheet and answered on the worksheet. Then, they wrote a summary.

When some students looked confused in doing some SQ3R steps, such as in conducting a survey step, the researcher explained again and wrote on the board, so that the students could understand more.

\section{Students' Responses toward the Implementation of SQ3R in Teaching Reading Comprehension}

In this research interview was conducted after the implementation of SQ3R. It consisted of four questions exploring students' responses toward the implementation of SQ3R. The questions in interviewing the students were carried in Indonesian, this was intended to gain clear understanding on what researcher and participants say (Rumhayati, 2012).

Table 2. Students' questionnaire

\begin{tabular}{cl}
\hline No & \multicolumn{1}{c}{ Question } \\
\hline 1. & $\begin{array}{l}\text { Are you interested in using SQ3R technique } \\
\text { while reading texts? Please explain your } \\
\text { answer! }\end{array}$ \\
\hline 2. & $\begin{array}{l}\text { Does reading using SQ3R enrich your } \\
\text { vocabulary or not? Why? }\end{array}$ \\
\hline 3. & $\begin{array}{l}\text { Does SQ3R help you to rewrite information } \\
\text { by your own words or not? Why? }\end{array}$ \\
\hline 4. & $\begin{array}{l}\text { What are the difficulties in reading English } \\
\text { text, how do you solve those difficulties? }\end{array}$ \\
\hline
\end{tabular}

The interview in this research was developed by formulating four (4) questions to gain in depth and clear information about students' responses toward the implementation of SQ3R in teaching reading comprehension.

The research focuses on the process and responses of the implementation of SQ3R (Survey, Question, Read, Recite, Review) technique in teaching reading comprehension.

\section{METHOD}

This research is conducted at one State Vocational High School in Purwakarta. The participants in this research are the high school third graders, while the researcher will be the teacher and participates as the observer of the implementation of SQ3R in teaching reading. However, there are only four students as the sample, whose ages are around 17 years old. The respondents are selected based on the principles of fairness and voluntary in which the researcher informed them before they were interviewed, and they were not forced to be interviewed (Herdiansyah, 2013).

In collecting the data, there are two instruments applied in this research, those are observation and interview. The first instrument is used to observe the activities in implementing SQ3R by completing observation sheets. The observation sheet is filled by the researcher who also participated as the teacher, and the complete notes are written in 
the field notes as quickly as possible after the observation (Cohen, Manion, \& Morrison, 2007; Satori \& Komariah, 2011). And, the second instrument is interview that was conducted after the implementation of SQ3R. The questions in interviewing the students were carried in Indonesian as to be intended to gain clear understanding on what the researcher and the participants say (Rumhayati, 2012).

This study uses the qualitative research. The research is intended to find out the way to describe the process of implementing SQ3R and the students' responses toward the implementation of SQ3R in teaching and learning reading comprehension. As mentioned in Hitchcock and Hughes (1995 as cited in Cohen, Manion, \& Morrison, 2007), a qualitative case study is used in this research in order to describe the events related to the case including process, how things occur, how students interact with their teacher as well as their friends in the classroom, and how questions are answered while implementing SQ3R in teaching reading comprehension.

\section{FINDINGS AND DISCUSSION}

\section{The Implementation of SQ3R in Teaching Reading Comprehension}

The text used as the materials in this research was narrative text. Before implementing SQ3R, on the first meeting, the students were given an explanation of how to do each step SQ3R in reading the text. As stated in Wright (2003) in (Lestari, 2018) that each step of SQ3R should be explained before implementing SQ3R because it will help the students in reading and understanding texts independently.

According to Marini (2014, as cited in Amin et al., 2008), SQ3R is five active steps of reading methods, surveying, questioning, reading, recite, and reviewing. This method is used to absorb fully written information and helps students become good readers. The steps of the implementation show as follow:

1. Survey (S), In this step, students are asked to survey the title of the text, the title of the text and each paragraph of the text to get a general understanding of the text and find the difficult word. Then students write difficult words and the title on their worksheet. The students are given 15 minutes to do the first step

2. Next step, the students are given 15 minutes to make a question $(\mathrm{Q})$ in their thought after doing survey, the researcher instructs students write to questions about the text and the information of each paragraph of the text, on their worksheets which include the question such as "what, where, who, why, and how"

3. Read (R1), the researcher instructs students to read the narrative text to find the answers to their questions written in step 2. The students are given 15 minutes to read the narrative text and find the answer from question in step 2.

4. Next meeting, recite (R2), the students write the main idea and response about the text. Then the researcher asks the students to repeat (aloud) in your own words what you have read. Explain what you have read to someone else. The students are given 15 minutes to do these steps. For Example: Students looked for the main idea of the narrative text and write down on a worksheet. As follow: Main idea of paragraph one: Once upon a time, there lived a widow woman and her son, Jack, on their small farm in the country.

5. Last step, Review (R3), the researcher asks students to review information and remember key points from supporting texts. Then, they were asked to write a summary of the text. This last step of SQ3R is useful for long-term remembering. The students are given 15 minutes to do write a summary.

From the experiences of the researcher when teaching using SQ3R, it is clear that the students were active and enthusiastic in asking the researcher when they had 
questions. In other words, they focused on doing the task given by the researcher. However, there were some students who looked shy to ask the teacher and waited until the teacher came close to his or her desk.

Each step of SQ3R was done in two meetings. For example, they surveyed the text by writing the title of the text and difficult words of the text on the survey worksheet. They also wrote some questions from the text on the worksheet and answered on the worksheet. Then, they also wrote a summary.

\section{From Data Interview}

From the interview, the students responded to the implementation of SQ3R in teaching and learning reading comprehension positively. From the students' statements, they were interested in the implementation of SQ3R in teaching reading texts because of some reasons: first, the technique was new for them. It helped them to understand the text better. Then SQ3R helped them to write questions from the text, to rewrite the information by their own words, and to write a report or summary about the text because it helped students to recall what had been read so that it lasts longer stored in memory. Then, it helped them to enrich their vocabulary as well because in every reading they would definitely find new vocabulary; this is significant, especially for those who learn foreign languages where rich vocabulary is very important.

\section{CONCLUSION}

The implementation of SQ3R helps students to understand English texts, and students respond positively to the application of SQ3R. Students are interested when reading English texts using SQ3R. They also focus when reading text using SQ3R. In addition, SQ3R helps students to write questions from the text, to rewrite information in their own words, and to write reports or summaries about the text. Finally, this helps them to enrich their vocabulary. However, there are some problems found in teaching reading comprehension using SQ3R. More time is needed to explain and give examples clearly to students. Thus, researchers need to consider the time allocation in implementing each SQ3R step.

\section{REFERENCES}

Amin, H. Al, Harmaini, F., \& Harha, K. (2008). Teaching Reading Comprehension by Using SQ3R to Senior High School. Ejurnal Bunghatta, 5.

Baier, K. (2011). The Effects OF SQ3R On Fifth Grade Students' Comprehension Levels. Fraenkel, J. R., Wallen, N. E., \& Hyun, H. H. (2012). How to Design and Evaluate Research in Education (8th ed.). New York: McGraw-Hill.

Hamra, A., \& Syatriana, E. (2010). Developing a Model Of Teaching Reading Comprehension For EFL Students. TEFLIN Journal, 21, 27-40.

Lestari, P. (2018). The Implementation of Assisting Student in Journal Article Reading Using SQ3R Method at The Shariah Accounting Department of IAIN Surakarta. The State Islamic Institute of Surakarta.

Masruuroh, M. S. (2015). SQ3R Implementation IN Teaching Reading Comprehension: A Case Study of Eight Grade Students at One State MTs in Sumedang. Journal of English and Education, 3(1), 106-121.

Miller, M., \& Veatch, N. (2010). Teaching Literacy in Context: Choosing and Using Instructional Strategies. The Reading Teacher, 64(3), 154-165. https://doi.org/10.1598/RT.64.3.1

Rahyana, T., Kasyulita, E., \& Rasyidah, U. (2016). The Effect Of SQ3R Technique Toward Students' Reading Comprehension Of Descriptive Texts At Grade Seventh 
The Journal of English Language Teaching, Literature, and Applied Linguistics [JELA]

Volume 1, Number 2, October 2019

Students OF SMP NEGERI 02 Pagarantapah Darussalam. Jurnal Mahasiswa FKIP Universitas Pasir Pengaraian, 2, 3-12. 